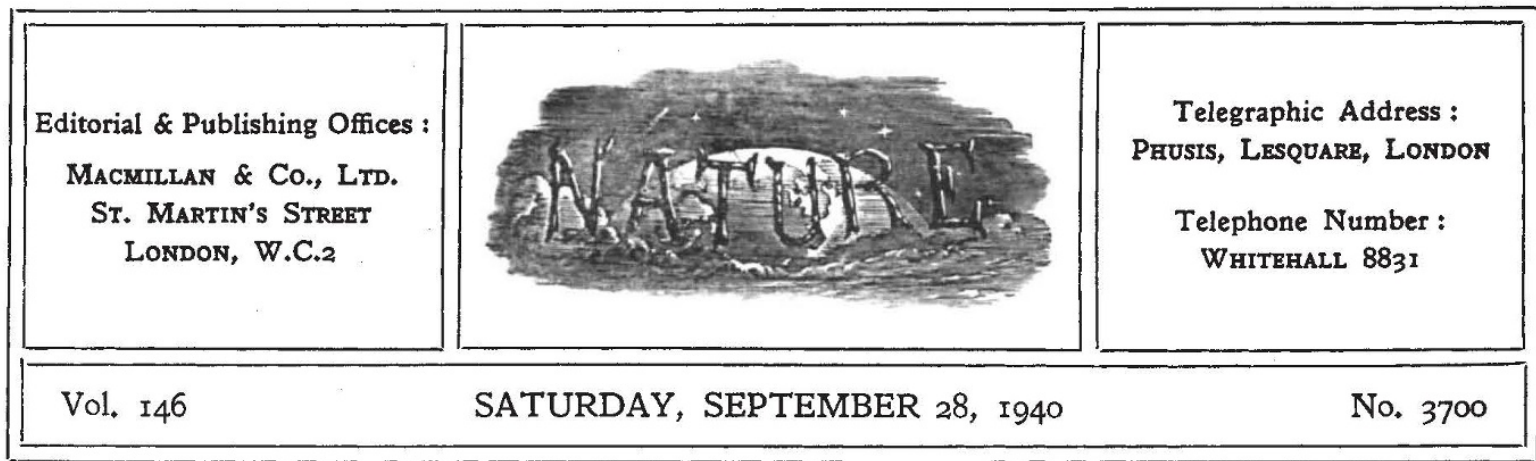

\title{
MORAL ISSUES OF THE WAR
}

$\mathrm{M}^{2}$ AZZINI'S specification for bayonets that they should have ideas at their points is now seldom referred to, but the value of this stipulation has been proved in many campaigns since those which led to the liberation of Italy. Under the conditions of totalitarian warfare, its importance indeed is enhanced, not merely for the armed forces but for also the whole population. Under the strain of intensified air warfare and the comparative inactivity to which the large forces at present in Great Britain are subjected, if morale is to be maintained, endurance fortified and fighting efficiency enhanced, we must see to it that the rank and file are afforded the fullest opportunity for recreation and mental stimulus, and that at the least they have a clear understanding of the cause in which they contend and the part they themselves have to play.

Indeed it may be said that the need to-day is for something more than ideas. We are resisting, for the most part alone, a tyranny which has repudiated and trampled under foot all the noblest and enduring values of European civilization. Fundamentally, this is a struggle between diametrically opposed ideals or ways of living, and in the intense strain which the conditions of modern warfare impose on the whole population, the inspiration which a great and enduring ideal can give may well sway the issue by the fortifying influence it can have on morale.

From this point of view alone it is difficult to over-stress the importance of a clear understanding of the issues involved in this struggle, and what success or failure means to each one of us. The admirable new series of Macmillan War Pamphlets are well designed to serve this purpose*. In contrast with the well-known Oxford Pamphlets on World Affairs, which deal more with concrete and special technical problems, they are concerned essentially with the moral and spiritual issues. They aim at reckoning our own liberties and contrasting this freedom with the bondage of our enemies; they probe the Nazi attitude to the Christian faith and they seek to examine and appraise the things for which we are fighting.

Not all the six pamphlets which have so far appeared are of equal merit. One or two of them are scarcely lucid enough to make the wide appeal that is the purpose of such a series, and err through intruding too much detail. There could, however, scarcely be a better statement of the issues in respect of freedom than the first pamphlet by Mr. A. P. Herbert. The struggle is between freedom and slavery, nothing less. A victory for Hitler would mean the spread of despotism and darkness; the victory of the Allies will mean the survival and the spread of light and liberty not in Europe only but wherever the sons of Adam dwell.

Mr. Herbert's succinct but searching analysis of what we understand by our liberties, with its fundamental concept of the value of the individual, ranging over the whole field of Parliament and Press and their responsiveness and sensitivity to public opinion, and its trenchant comparison with conditions in Germany, is indeed a stimulus to the lukewarm and half-hearted, and more than justifies his contention that there cannot and should not

* Macmillan War Pamphlets. Let There be Liberty. By A. P. Herbert. War with Honour. By A. A. Milne. The Crooked Cross. By Dr. A. S. Duncan-Jones. Nazi and Nazarene. By Ronald Knox. By E. M. Forster. (London: Macmillan and Co., Ltd.) 3d. net each. 
be neutrality in this War. We must either stand up in defence of freedom of thought, of speech, of worship, of Press and Parliament, with all that their continuance means in science, in art, in literature and music, or betray all that great moral, spiritual and intellectual heritage that has come to us from the past.

To recognize that we are the bearers of a noble trust and high responsibility is indeed heartening in days of trial. Mr. Milne's "War with Honour" aptly follows in the same theme and strikes with convincing realism into many of the pacifist arguments which seem so far removed from the world in which we find ourselves to-day. Mr. Milne points out that there are in theory three possibilities : the victory of Britain; the victory of Germany; or peace without victory. The third possibility, whether it involves leaving Hitler in possession of what he has already won, which is tantamount to a German victory, or in possession of no more of German Europe than is rightfully hers, which would be a British victory, is a wholly ineffective starting-point for the elimination of war.

Mr. Milne contends, therefore, that the only hope for the establishment of peace as desired by the pacifist lies in a victory for Britain. We have reached, he considers, a stage in human progress when the vast majority of the peoples of the world are pacifists, realizing alike the futility and the increasing barbarism of war. In a democratic country the main body of the people marks the stage of civilization which that country has reached, and for this reason offers a safeguard for peace which cannot be offered by an autocracy where the individual gangster may be the autocrat.

Mr. Milne frankly admits that the emergence of Hitler has invalidated all that he previously wrote about peace and war in "Peace with Honour". He affirms his conviction that if unresisted the abomination of Nazi rule will spread over and corrupt the whole world, and that in such a Nazi world there can be no place for decency, honesty or humanity. No man of courage, intelligence or imagination, no man who has a kindly thought for his neighbour or compassion for the innocent, no lover of truth, of beauty or of God can find a place in that world. It is this conviction that leads him to assert that it is the duty of mankind to reject such a world as much as it is the duty of a community to reject gangster rule. Only when this has been done by the use of force can civilization resume its march.
No less passionately in "Nordic Twilight", Mr. E. M. Forster affirms his belief that if the Nazis won they would destroy our civilization, and he points to the blank faces of German soldiers and airmen in any close-up photograph as showing that they have been cheated of their inheritance by a perverted education, and ruined mentally so that they may better spread ruin. Convincingly Mr. Forster shows how achievement in art and literature, in science and philosophy, is linked up with freedom of personality and expression. Already before the War German contributions in these fields were deteriorating because her culture had been allowed to become governmental. It was no longer genuinely national and capable of contributing to the general good of humanity.

The tragic picture which Mr. Forster draws of the way in which Germany's great cultural heritage has been violated by Nazi rule and its expression suppressed is paralleled by one of what is already being done to the culture of occupied or conquered countries, and a forecast of what might be done to our own if Germany should win. The picture demonstrates the impossibility of coming to terms with Hitler. A peace resulting from a Nazi victory would merely mean that Germans would no longer be killed, but they would go on killing others until no one survived to criticize them.

In the world domination thus achieved there could be no culture and no creative genius, for in their brutality and destruction the Nazis are destroying their own life. The passionate understanding which is at the heart of creation, no less than the calm use of the intellect--these are what the Nazi regime atrophies and destroys; to-day they are in the hands of the democracies to defend. It is the whole order of life that is based upon the dignity and eternal value of the individual human soul that is at stake, and these pamphlets well supply an interpretation of the issues and an understanding of what is involved that cannot but be heartening in one of the sternest hours of the struggle.

Mr. Forster closes on a note that harmonizes with those struck in two other of the pamphlets, in which the Dean of Chichester and Monsignor Knox describe the struggle inside Germany of the Protestant Church, the Confessional Church and the Roman Catholic Church against Hitler. Both alike lay bare the Nazi purpose of the eradication of Christianity altogether, and if at times these two pamphlets may seem a little too detailed for the general reader he can be left in no doubt as 
to the virulence of the campaign of this new paganism against the Christian Church as such. Such a reader may well marvel at the divisions of the Church which permitted Hitler in his usual way to play off one against another, but he may also wonder whether at last the realization that all the enduring values of Christianity, the traditions and thought which have so enriched the culture and civilization of Europe are at stake, may not in the face of a common peril effect a reconciliation and an understanding which are long overdue.

Mr. J. R. Clynes strikes a different note. The case for democracy against totalitarianism does not rest alone on moral and spiritual values. We are too apt to forget that democracy has a record of material progress and of the redress or removal of social injustice which no dictatorship can approach. It is to the revolution in social conditions which he has witnessed in his own lifetime that Mr. Clynes directs attention. In the vivid picture he gives in the pages of this pamphlet of the way in which conditions have changed over the whole field of education and child welfare, of industry, of unemployment and of housing, he does not conceal the fact that we have still far to go before we can rest content. None the less it is a heartening picture he draws of a silent social revolution which is still going on, giving a new sense of security and a rising standard of health and living, and in the reconstruction to follow the War should be accelerated.
Under our democratic institutions there have been indeed solid and revolutionary gains in a single lifetime. Even from a material point of view alone there are rights and privileges which we have won for ourselves and which it is an honour and a duty to defend. Built up on ordered freedom and reason and a respect for human rights and the individual soul, this civilization of ours must be upheld by every means that is just and right. To surrender one inch to the claims of Hitlerism is to endanger not merely the liberties which are the basis of all that is noblest in our cultural and spiritual heritage but also all that has been built up in the social sphere.

These pamphlets, appearing at a time when the struggle is being intensified and fiercer demands are made on our powers of endurance, are admirably calculated to fortify our resolution by the lucid way in which the issues are set before us. The choice is indeed between a victory for the enduring values of our civilization or a slavery and barbarism to which the pages of history can offer no parallel. In the heat of the struggle it is well indeed to be reminded of the greatness of our responsibility, of the solid achievements which form part of our heritage, and to glimpse something also of the possibilities of adding yet more splendid pages to that record when this present threat to the whole human race has been once and for all overthrown.

\section{BIRDS OF BRITAIN}

\section{The Handbook of British Birds}

By H. F. Witherby (Editor), Rev. F. C. R. Jourdain, Norman F. Ticehurst and Bernard W. Tucker. Vol. 4: Cormorants to Crane. Pp. xiv $+461+$ plates 93-125. (London: H. F. and G. Witherby, Ltd., 1940.) 21s. net.

THE fourth volume of the "Handbook of 1 British Birds" is fully up to the high standard set by the previous three volumes. The birds described in the present volume are the shags, cormorants and gannets, the petrel family (including the fulmar and the shearwaters), grebes and divers. There are full accounts of the waders, such as curlew and whimbrel, the godwits, woodcock and snipe, red-necked phalarope, turnstone, dunlin and lapwing, dotterel and golden plover, greenshank and redshank, stone curlew and oyster catcher.
Since volume 3 was produced, the authors have suffered a heavy loss by the death of the Rev. F. C. R. Jourdain, one of the most learned and distinguished ornithologists of his time. In the words of the editor of the present volume:

"It is deeply to be regretted that Mr. Jourdain, who took such an intense interest in this work, was not spared to see its completion, but he has left most careful notes and records from which can be drawn the accounts of the remaining species.

"For this work we are glad to be able to say that we have been promised the co-operation of Mr. W. B. Alexander, Director of the Edward Grey Institute of Field Ornithology at Oxford, who with the consent of the University Committee for Ornithology has kindly undertaken the completion of the 'Distribution Abroad' sections for the present volume and will write both these and the 'Food' sections for volume v. Mr. Alexander's 